\title{
Ornamental Types in Castor Oil Plant
}

\author{
Anubhava Narain \\ (Department of Agriculture, Bihar, India)
}

The castor oil plant is very much polymorphic in nature. Some of the forms besides being agronomical are also highly ornamental. A reference to it is made by Duthie (1911) in his 'flora' that 'the plant is much cultivated in gardens for the sake of the brightly coloured foliage of some of its varieties.' The author, while classifying the various forms and studying its genetics, made efforts to enrich some of the ornamental forms through collection and breeding at Government Research Farm, Kanpur. The various ornamental forms reported here in addition to having brightly coloured foliage also show the combination of various shades of attractive colour running through out the vegetitave parts viz., stem, petiole, leaves, capsule and spine with bloomless habit and spiny or spineless character of the fruit.

\section{DESCRIPTION OF ORNAMENTAL TYPES SELECTED AT GOVERNMENT RESEARCH FARM, KANPUR.}

O. Type 1:- This variety is a selection from the original heterozygous material viz., 2183 B from Australia. The selfed selected plant is breeding pure since 1953-54. The stem, petiole, leaves, capsule and spines are all burnt lake coloured. It is completely bloomless and iruits are spiny (Fig. 3).

o. Type 2:- This variety was evolved as a result of hybridization between 0 . Type 1 and $4102 \mathrm{P}$ mut. (a rose red and spineless variety). It has all the characters of $O$. Type 1 except that the fruits are spineless (Fig. 4).

O. Type 3 :- This variety is a selection from the cross between types $4102 \mathrm{P}$ mut. and $4101 \mathrm{D}$. The stem and petiole are pomegranate and leaves bordeaux in colour. The fruits on the sunny side are bordeaux coloured, the extent of which is about $3 / 4$ of the surface of capsule. It is completely bloomless and spineless (Fig. 8).

o. Type 4:- This variety is also a selection from the above cross. It has all the above characters except that the fruits are spiny (Fig. 7).

O. Type 5:- This variety has been obtained as a result of selection from the cross between types $4101 \mathrm{D}$ and $\mathrm{T} 9$. The stem and petiole are pomegranate. The leaves are green. The extent of bordeaux colour on the sunny side of the fruit is very small i.e. $1 / 3$ of the total area, the remaining surface is green (Fig. 12). It is completely bloomless and spineless.

O. Type 6:- This variety has also been selected from the above cross and has all the characters as that of O.T. 5 except that the fruits are spiny (Fig. 11).

Recieved for publication on March 19, 1960.

Journal of the Horticultural Association of Japan 29 (4) : 331-332. 1960. 
o. Type $7:-$ This variety is a collection from the Botanical Garden, Kanpur. The stem, petiole, leaves, fruits and spines are all pomegranate coloured. It is bloomless and fruits are spiny (Fig. 1).

O. Type 8:- This variety is a selection from the cross between O.T. 7 and $4102 \mathrm{P}$ mut., and has all the characters of O.T. 7 except that it is spineless (Fig. 2).

o. Type 9:- This variety is a selection from the original heterozygous material 21848 from Australia. The stem, petiole and fruits are rose pink in colour. The leaves are green. It is bloomless and the fruits are spineless (Fig. 6).

O. Type 10:- This variety is an another selection from the above material. It has all the above characters except that the fruits are spiny (Fig. 5).

O. Type $11:-$ This variety is a selection from the cross between O.T. 7 and O. T. 5 (a green spineless form). The stem, petiole fruits and spines are all light green in colour. It is bloomless, spineless and leaves are green (Fig. 10).

o. Type $12:-$ This variety is an another selection from the above cross. It has all the characters of O.T. 11 except that the fruits are spiny (Fig. 9).

The author is grateful to Dr. D. P. SINGH, Economic Botanist (Oilseeds) to Government, U.P., Kanpur, for facilities, encouragement and criticism.

Note :- The colour of all the ornamental types described, has been compared with 'Colour Standards' by RIDGWAY.

\section{References}

1. DUTHIE, J. F. 1903-11. Flora of the upper gangetic plain and adjacent Sivalik and SubHimalayan Tracts.

2. RIDGWAY, R. 1912. Colour standards and colour nomenclature.

ヒマの観賞用の諸型

\begin{tabular}{|c|c|}
\hline 摘 & 要 \\
\hline ヒマは油料作物として知られているが，元来変異に富 & に刺のあるるの, ないるのなど 12 型を選んで, その記 \\
\hline てでいて観賞価値の高いるのもある。著者はヒマの分類 & 載を行ない，また図で示した。これらの中いくつかは交 \\
\hline および遺伝の研究中各種のタイプのものを集めたが，そ & 配選抜によつて得られたものである。 \\
\hline
\end{tabular}

の中，茎葉や果実浾〈美しい色素を有するるの，果実 


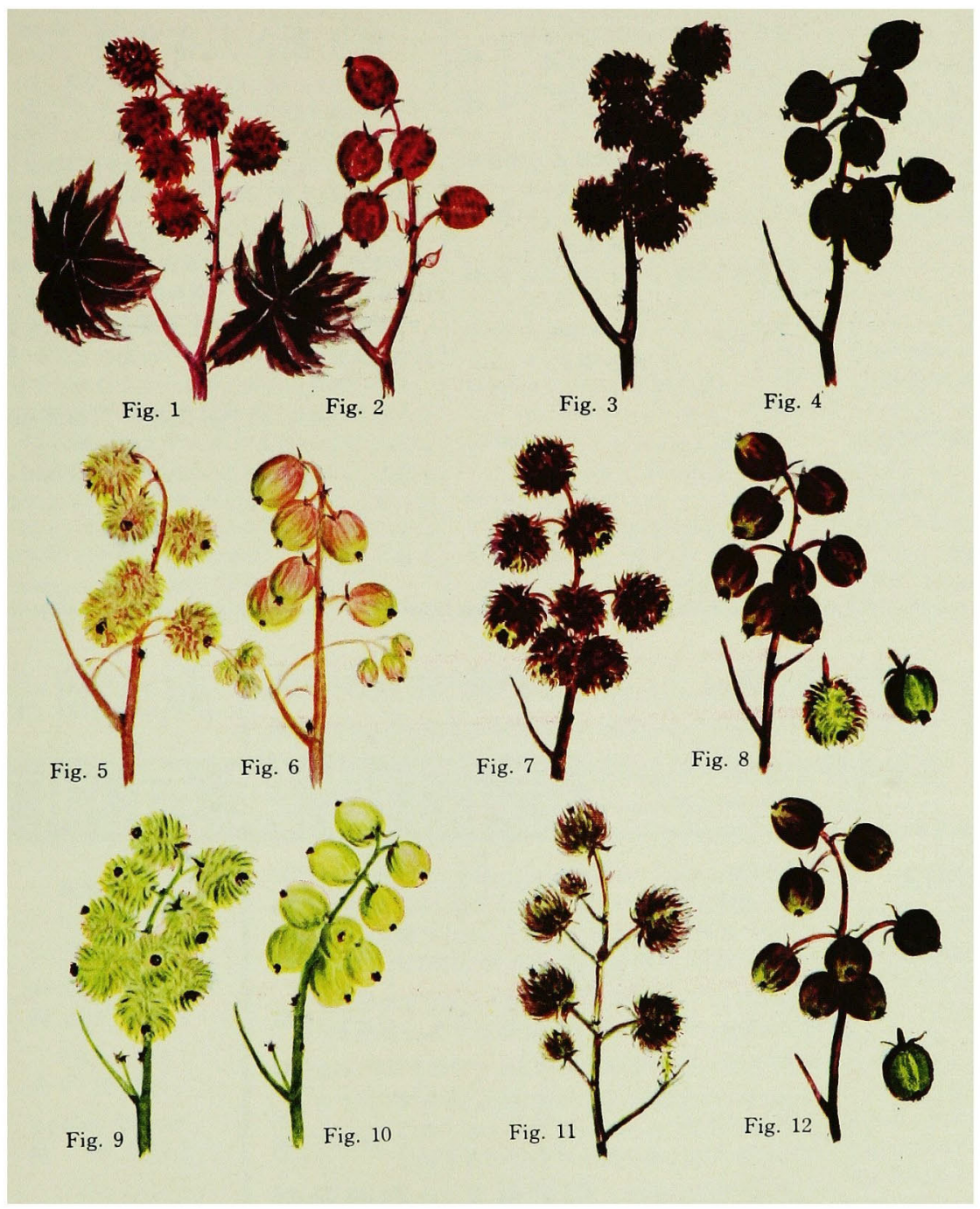

